\title{
Proses Metakognitif Siswa SMA dalam Pengajuan Masalah Geometri
}

\section{YULI SUHANDONO}

Email : mas.yulfi@gmail.com

\begin{abstract}
Abstrak :
Penelitian ini bertujuan untuk mendeskripsikan proses metakognitif siswa dalam pengajuan masalah geometri. Subjek penelitian adalah siswa kelas X sebanyak 2 siswa berdasarkan kategori pada tes pengajuan masalah tipe post-solution. Hasil penelitian ini menunjukkan bahwa proses metakognitif subjek kategori pertama dalam pengajuan masalah geometri, melakukan aktivitas merencanakan, memantau dan mengevaluasi proses dan hasil berpikirnya pada setiap tahap pengajuan masalah (memahami informasi, menyusun rencana pengajuan masalah, merumuskan masalah, menyelesaikan masalah dan memeriksa kembali kesesuaian masalah yang dibuat dengan informasi awal). Proses metakognitif subjek kategori kedua dalam pengajuan masalah geometri, melakukan aktivitas merencanakan, memantau dan mengevaluasi proses dan hasil berpikirnya pada tahap memahami informasi, menyusun rencana pengajuan masalah dan merumuskan masalah. Sedangkan pada tahap menyelesaikan masalah subjek kategori kedua melakukan aktivitas merencanakan dan memantau proses berpikirnya tetapi tidak melakukan aktivitas mengevaluasi proses dan hasil berpikirnya. Selain itu pada tahap memeriksa kembali kesesuaian masalah yang dibuat dengan informasi awal subjek kategori kedua melakukan aktivitas memantau dan mengevaluasi proses dan hasil berpikirnya tetapi tidak melakukan aktivitas merencanakan proses berpikirnya.
\end{abstract}

Kata kunci: Metakognitif, Pengajuan Masalah, Masalah Geometri.

\section{Pendahuluan}

Geometri merupakan bagian dari matematika yang erat kaitannya dengan masalah yang ada dalam kehidupan sehari-hari. Beberapa tujuan belajar geometri adalah mengembangkan kemampuan berpikir logis, menanamkan pengetahuan untuk menunjang materi yang lain dan mampu membangun argumen-argumen matematika mengenai hubungan geometri dengan lainnya (Budiarto, 2000; NCTM, 2007). Pada dasarnya geometri seharusnya lebih mudah dipahami oleh siswa dibandingkan dengan cabang matematika yang lain. Namun pada kenyataannya, masih banyak siswa yang mengalami kesulitan dalam memecahkan masalah geometri di tingkat sekolah menengah. Sejalan dengan Madja (Abdussakir, 2009) bahwa hasil tes geometri siswa SMA kurang memuaskan jika dibandingkan dengan materi matematika yang lain.

Resnick (1987) mengungkapkan bahwa untuk meningkatkan kemampuan 
pemecahan masalah siswa dapat dilatih dengan memberikan stimulus kepada mereka dalam menganalisis masalah, membuat pertanyaan dan memprediksi situasi yang diberikan. Silver \& Cai (1996) menyatakan kemampuan siswa sekolah menengah dalam pengajuan masalah mempunyai hubungan yang kuat dan positif dengan kemampuan pemecahan masalah. Sedangkan Siswono (2002) menyatakan ketika seorang siswa dapat mengajukan masalah dengan baik maka baik pula dalam menyelesaikan suatu masalah. Oleh sebab itu siswa akan termotivasi dalam pemecahan masalah jika telah mengajukan masalah berdasarkan kebutuhan dan kesadaran mereka sendiri.

Seorang guru perlu mempertimbangkan banyak hal dalam memilih strategi untuk mengajarkan suatu materi kepada siswa. Weinstein \& Mayer (Arends, 1997) bahwa pengajaran yang baik meliputi mengajar siswa tentang bagaimana belajar, bagaimana mengingat, bagaimana berpikir, dan bagaimana memotivasi diri sendiri. Flavell (1976) menyebut aktivitas berpikir tentang berpikirnya sendiri sebagai metakognisi. NCREL (1995) mengemukakan tiga dasar metakognisi yaitu mengembangkan rencana tindakan, memonitor rencana tindakan dan mengevaluasi rencana tindakan.

Adapun penelitian yang berhubungan dengan metakognisi maupun pengajuan masalah yang telah dilakukan oleh Yeap (1997), Desoete (2007), Dawson \& Fucher (2008), Kuzle (2011), Sudia (2013), dan Karnain (2014) mendorong peneliti untuk mendeskripsi- kan proses metakognitif siswa dalam hal merencanakan proses berpikirnya, memantau proses berpikirnya serta mengevaluasi proses dan hasil berpikirnya dalam pengajuan masalah geometri yang dirasa peneliti masih belum banyak dilakukan oleh peneliti lain.

\section{Metode}

Jenis penelitian ini adalah deskriptif kualitatif yang bertujuan untuk mendeskripsikan proses metakognitif siswa SMA dalam pengajuan masalah geometri. Penelitian dilakukan di SMA Negeri 3 Sidoarjo. Subjek penelitian sebanyak 39 siswa kelas X MIPA2. Instrumen utama adalah peneliti sendiri sedangkan instrumen pendukung terdiri dari tes pengajuan masalah geometri (TPMG) dan pedoman wawancara. Adapun tes pengajuan masalah geometri ditampilkan pada Gambar 1 berikut.

\section{MASALAH 1}

Diketahui kubus ABCD.EFGH dengan panjang rusuk $6 \mathrm{~cm}$. Hitunglah jarak titik $B$ ke bidang AFC!

\section{PERINTAH:}

1. Selesaikan masalah tersebut!

2. Berdasarkan masalah yang sudah kamu selesaikan, buatlah masalah baru yang lebih rumit daripada masalah awal dan selesaikan masalah tersebut!

Gambar 1. Tes Pengajuan Masalah Geometri (TPMG)

\begin{tabular}{|c|c|c|}
\hline \multicolumn{2}{|c|}{$\begin{array}{c}\text { Kategori Siswa dalam } \\
\text { Melaksanakan TPMG1 }\end{array}$} & Jumlah \\
\hline K1 & $\begin{array}{l}1.1 \\
\text { Siswa dapat } \\
\text { menyelesaikan } \\
\text { masalah awal dengan } \\
\text { benar }\end{array}$ & 5 \\
$1.2 \begin{array}{l}\text { Siswa dapat membuat } \\
\text { masalah dengan benar }\end{array}$ & \\
\hline
\end{tabular}




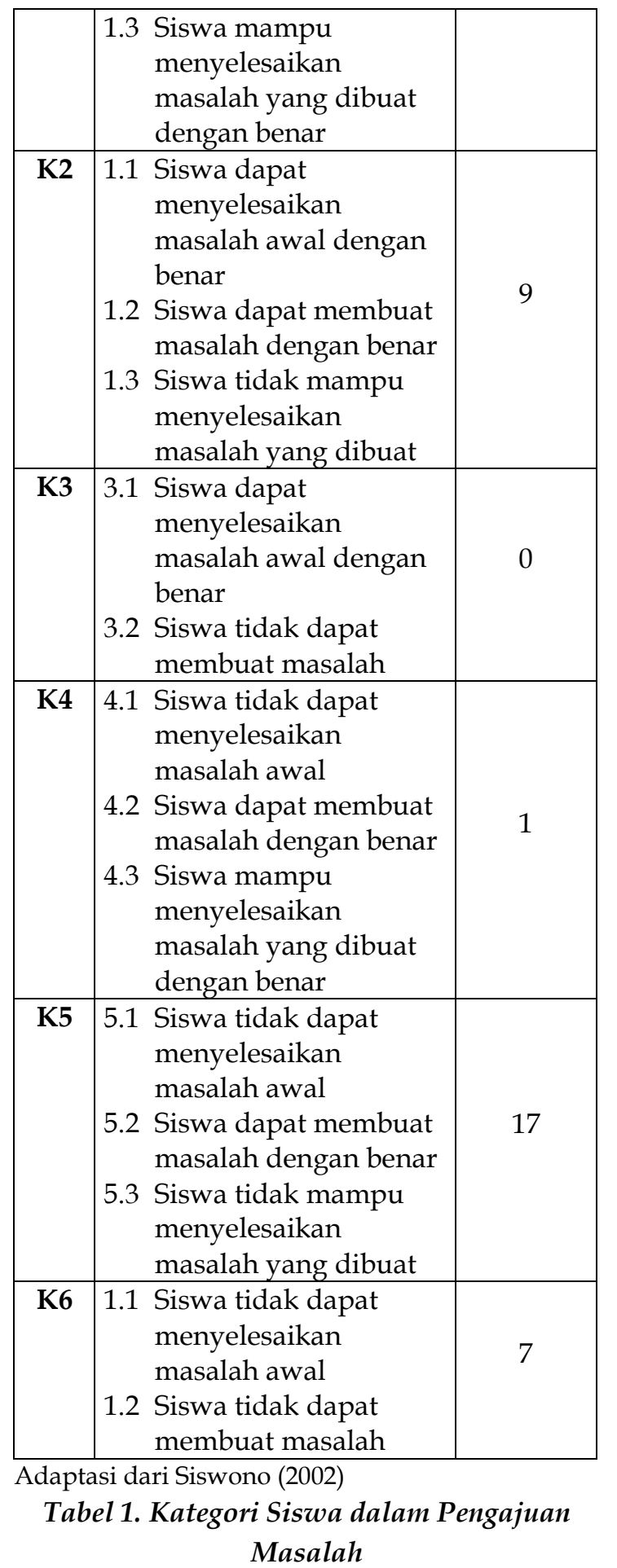

Teknik pengumpulan data dalam penelitian ini adalah (1) peneliti memberikan TPMG pada subjek (2) sebelum, pada saat dan setelah mengajukan masalah subjek melakukan think-aloud pada saat diwawancarai dan (3) peneliti melakukan perekaman secara audio maupun visual pada saat wawancara. Analisis data dalam penelitian ini yaitu reduksi data, penyajian data, dan penarikan kesimpulan yang mengacu pada Miles dan Huberman (dalam Sugiyono, 2011).

\section{Hasil dan Pembahasan}

Berdasarkan hasil pre-tes pengajuan masalah geometri yang telah dikategorikan, dipilih 2 subjek berdasarkan kategori yang sesuai dengan pengajuan masalah tipe post-solution yaitu subjek 1 (S1) yang berjenis kelamin laki-laki dan subjek 2 (S2) yang berjenis kelamin perempuan. Selanjutnya, hasil karakteristik proses metakognitif subjek dalam pengajuan masalah geometri dipaparkan dengan mengacu pada setiap komponen indikator proses metakognitif yaitu merencanakan, memantau dan mengevaluasi.

Komponen dari merencanakan ada 5 indikator yaitu sadar terhadap proses dan hasil berpikirnya, dalam merencanakan apa yang akan dilakukan untuk memahami informasi (AR), sadar terhadap proses dan hasil berpikirnya, dalam merencanakan hal yang akan dilakukan untuk menyusun rencana dalam pengajuan masalah (BR), sadar terhadap proses dan hasil berpikirnya, dalam merencanakan hal yang akan dilakukan untuk merumuskan masalah dengan memikirkan akan menggunakan susunan kalimat seperti apa pada penulisan masalah yang dibuat (CR), sadar terhadap proses dan hasil berpikirnya, dalam merencanakan untuk menggunakan rencana yang telah dibuat untuk menyelesaikan masalahnya (DR) 
dan sadar terhadap proses dan hasil berpikirnya, dalam merencanakan saat akan memeriksa kembali masalah yang dibuat (ER).

Komponen dari memantau ada 5 indikator yaitu sadar terhadap proses dan hasil berpikirnya, dalam memantau langkah yang dilakukan dalam memahami informasi (AM), sadar terhadap proses dan hasil berpikirnya, dalam merencanakan hal yang akan dilakukan untuk menyusun rencana dalam pengajuan masalah (BM), sadar terhadap proses dan hasil berpikirnya, dalam memantau hal yang dilakukan dalam merumuskan masalah (CM), sadar terhadap proses dan hasil berpikirnya, dalam memantau penggunaan rencana penyelesaian yang telah dibuat untuk menyelesaikan masalahnya (DM) dan sadar terhadap proses dan hasil berpikirnya, dalam memantau pemeriksaan kembali masalah yang dibuat (EM).

Komponen dari evaluasi ada 5 indikator yaitu sadar terhadap proses dan hasil berpikirnya, dalam mengevaluasi langkah yang digunakan dalam memahami informasi (AE), sadar terhadap proses dan hasil berpikirnya, dalam mengevaluasi hal yang dilakukan dalam menyusun rencana pengajuan masalah (BE), sadar terhadap proses dan hasil berpikirnya, dalam mengevaluasi hal yang dilakukan dalam merumuskan masalah (CE), sadar terhadap proses dan hasil berpikirnya, dalam mengevaluasi kebenaran penggunaan langkah dan hasil penyelesaian apakah telah sesuai rencana atau belum (DE) dan sadar terhadap proses dan hasil berpikirnya, dalam mengevaluasi pemeriksaan kembali masalah yang dibuat (EE).

\section{Proses Metakognitif Subjek 1 (S1)}

Pada subjek S1 dalam pengajuan masalah telah menunjukkan proses metakognitif pada aktivitas merencanakan, memantau dan mengevaluasi dalam setiap tahapan pengajuan masalah yaitu $\mathrm{AR}, \mathrm{AM}, \mathrm{AE}, \mathrm{BR}, \mathrm{BM}, \mathrm{BE}, \mathrm{CR}, \mathrm{CM}, \mathrm{CE}$, DR, DM, DE, ER, EM, dan EE.

Pada saat memahami informasi, subjek melibatkan aktivitas metakognitif dalam merencanakan pada saat memikirkan cara memahami informasi dengan cara membaca perintah kedua dan mempelajari kembali masalah awal; melibatkan aktivitas metakognitif dalam memantau saat mengecek pemahaman informasi yaitu dengan cara mengungkapkan informasi yang dipahami pada perintah kedua, mengungkapkan informasi yang dipahami pada masalah awal, dan saat mengetahui adanya informasi lain yang dipahami pada masalah awal yaitu dengan cara memperhatikan kembali masalah awal; melibatkan aktivitas metakognitif dalam mengevaluasi saat memeriksa pemahaman informasi yaitu dilakukan dengan cara memperhatikan kembali perintah kedua dan masalah awal, saat memeriksa kesesuaian informasi yang diungkapkan dari yang dipahami pada perintah kedua maupun masalah awal dengan cara memperhatikan perintah kedua dan masalah awal.

Pada saat menyusun rencana pengajuan masalah, subjek melibatkan aktivitas metakognitif dalam merencanakan pada saat memikirkan bentuk 
bangun ruang, ukuran bangun dan pertanyaan pada masalah yang akan dibuat; melibatkan aktivitas metakognitif dalam memantau saat mengecek apa saja yang harus direncanakan sebelum menyusun masalah, yaitu dengan cara mengungkapkan bangun ruang, ukuran bangun ruang dan pertanyaan yang akan dipakai pada masalah yang akan dibuat dan saat mengecek ide asal dan alasan akan menggunakan ide tersebut, yaitu dengan cara mengungkapkan ide asal yang dipikirkan dan alasan memikirkan ide tersebut dalam menyusun rencana pengajuan masalah; melibatkan aktivitas metakognitif dalam mengevaluasi saat memeriksa kembali masalah yang sudah dipikirkan, yaitu dilakukan dengan cara membuat dan mengamati kembali oretoretan ketika memeriksa tingkat kesulitan masalah yang akan dibuat, saat memeriksa kembali masalah yang sudah dipikirkan akan bisa diselesaikan, yaitu dengan menyatakan yakin bahwa masalah yang dipikirkan bisa diselesaikan; dan saat memeriksa kesesuaian rencana dalam menyusun masalah dengan informasi sebelumnya yang diperoleh, yaitu dilakukan dengan cara memperhatikan kembali masalah awal maupun perintah kedua.

Pada saat merumuskan masalah, subjek melibatkan aktivitas metakognitif dalam merencanakan pada saat memikirkan dan menuliskan masalah yang dipikirkan; melibatkan aktivitas metakognitif dalam memantau saat mengecek masalah yang dibuat ketika menyelidiki kebenaran apa yang ditulis dan saat menyelidiki apakah masalah yang dibuat mudah dipahami, yaitu dengan cara membaca kembali masalah yang dibuat; melibatkan aktivitas metakognitif dalam mengevaluasi saat menyelidiki kesesuaian pelaksanaan rencana dalam merumuskan masalah, yaitu dengan cara mengamati kembali masalah yang dibuat.

Pada saat menyelesaikan masalah, subjek melibatkan aktivitas metakognitif dalam merencanakan pada saat memikirkan untuk mencoba menyelesaikan masalah yang dibuat, saat memikirkan dan mengungkapkan langkah dan hasil akhir penyelesaian masalah yang dibuat; melibatkan aktivitas metakognitif dalam memantau saat menyelidiki kebenaran langkah dan hasil akhir penyelesaian masalah yang dibuat, yaitu dengan cara mengecek kembali langkah dan hasil akhir penyelesaian masalah yang dibuat; melibatkan aktivitas metakognitif dalam mengevaluasi saat menyelidiki kesesuaian pelaksanaan rencana dalam menyelesaikan masalah yang dibuat, yaitu dengan cara mengamati kembali apa yang sudah dikerjakan.

Pada saat memeriksa kembali, subjek melibatkan aktivitas metakognitif dalam merencanakan pada saat memikirkan untuk memeriksa kembali masalah yang dibuat, saat memikirkan dan mengungkapkan apa yang dipikirkan ketika memeriksa kembali kesesuaian masalah yang dibuat dengan informasi awal; melibatkan aktivitas metakognitif dalam memantau saat mengecek kembali masalah yang dibuat, perintah kedua dan masalah awal ketika menyelidiki kesesuaian masalah yang dibuat dengan informasi awal; melibatkan aktivitas 
metakognitif dalam mengevaluasi saat memperhatikan kembali masalah yang dibuat ketika meyakinkan pada diri sendiri bahwa masalah yang dibuat sudah sesuai dengan informasi awal; dan saat mengoreksi potensi diri sendiri dalam mengajukan masalah.

\section{Proses Metakognitif Subjek 2 (S2)}

Pada subjek S2 selama pengajuan masalah telah menunjukkan proses metakognitif pada aktivitas merencanakan, memantau dan mengevaluasi dalam tahapan pengajuan masalah, namun tidak melakukan proses metakognitif yang melibatkan aktivitas evaluasi pada tahap menyelesaikan masalah yang dibuat dan tidak melakukan proses metakognitif yang melibatkan aktivitas mengembangkan rencana dalam memeriksa kembali masalah yang dibuat yaitu $\mathrm{AR}, \mathrm{AM}, \mathrm{AE}$, $\mathrm{BR}, \mathrm{BM}, \mathrm{BE}, \mathrm{CR}, \mathrm{CM}, \mathrm{CE}, \mathrm{DR}, \mathrm{DM}, \mathrm{EM}$, dan EE.

Pada saat memahami informasi, subjek melibatkan aktivitas metakognitif dalam merencanakan pada saat memikirkan memikirkan cara memahami informasi yaitu dengan cara membaca perintah kedua; melibatkan aktivitas metakognitif dalam memantau saat mengecek pemahaman informasi yaitu dengan cara mengungkapkan informasi yang dipahami pada perintah kedua; melibatkan aktivitas metakognitif dalam mengevaluasi saat memeriksa pemahaman informasi yaitu dilakukan dengan cara memperhatikan kembali perintah kedua; dan saat memeriksa kesesuaian informasi yang diungkapkan dari yang dipahami pada perintah kedua dengan cara memperhatikan perintah kedua.

Pada saat menyusun rencana pengajuan masalah, subjek melibatkan aktivitas metakognitif dalam merencanakan saat memikirkan dan mengungkapkan bangun ruang yang akan dipakai dan memikirkan juga ukuran bangun ruang pada masalah yang akan dibuat, saat mengungkapkan bahwa ada lagi rencana selanjutnya yaitu memikirkan dan mengungkapkan pertanyaan pada masalah yang akan dibuat dan saat mengungkapkan bahwa dia hanya memikirkan masalah yang lebih susah dari masalah sebelumnya tanpa memikirkan penyelesaiannya; melibatkan aktivitas metakognitif dalam memantau saat mengungkapkan ukuran bangun ruang yang akan dipakai pada masalah yang akan dibuat beserta alasan memilih ukuran tersebut, saat mengungkapkan ide asal yang dipikirkan dalam menyusun rencana pengajuan masalah dan saat mengecek adanya rencana lain selain yang diungkapkan dengan menyatakan tidak ada rencana lain selain yang sudah diungkapkan; melibatkan aktivitas metakognitif dalam mengevaluasi memeriksa tingkat kesulitan masalah yang akan dibuat yaitu, dengan cara memperhatikan oret-oretan yang dibuat dan saat memeriksa kesesuaian rencana dalam menyusun masalah dengan informasi sebelumnya yang diperoleh, yaitu dengan cara memperhatikan kembali masalah awal dan perintah kedua.

Pada saat merumuskan masalah, subjek melibatkan aktivitas metakognitif 
dalam merencanakan pada saat memikirkan dan menuliskan masalah yang dipikirkan; melibatkan aktivitas metakognitif dalam memantau saat mengecek masalah yang dibuat ketika menyelidiki kebenaran apa yang ditulis dan saat menyelidiki apakah masalah yang dibuat mudah dipahami, yaitu dengan cara membaca kembali masalah yang dibuat; melibatkan aktivitas metakognitif dalam mengevaluasi saat menyelidiki kesesuaian pelaksanaan rencana dalam merumuskan masalah, yaitu dengan cara mengamati kembali masalah yang dibuat.

Pada saat menyelesaikan masalah, subjek melibatkan aktivitas metakognitif dalam merencanakan pada saat memikirkan untuk mencoba menyelesaikan masalah yang dibuat; melibatkan aktivitas metakognitif dalam memantau saat menyelidiki potensi diri dalam menyelesaikan masalah yang dibuat yaitu, dengan merasa kesulitan mencari cara penyelesaian masalah kedua yang dibuat; subjek tidak melakukan proses metakognitif yang melibatkan aktivitas evaluasi pada tahap menyelesaikan masalah yang dibuat.

Pada saat memeriksa kembali, subjek tidak melakukan proses metakognitif yang melibatkan aktivitas mengembangkan rencana dalam memeriksa kembali masalah yang dibuat; melibatkan aktivitas metakognitif dalam memantau saat mengecek kembali masalah yang dibuat dan perintah kedua ketika menyelidiki kesesuaian masalah yang dibuat dengna informasi awal; melibatkan aktivitas metakognitif dalam mengevaluasi saat memperhatikan kembali masalah yang dibuat ketika meyakinkan pada diri sendiri bahwa masalah yang dibuat sudah sesuai dengan informasi awal; dan saat mengoreksi potensi diri sendiri dalam mengajukan masalah.

Adapun temuan dari hasil penelitian ini yaitu ketika menyelesaikan masalah yang dibuat, subjek S1 menggunakan pengetahuan prasyarat seperti rumus phytagoras, kesebangunan dan trigonometri. Hal ini sependapat dengan Gagne, Briggs \& Wager (1992) bahwa suatu topik matematika dipelajari bila hirarki prasyaratnya telah dipelajari. Subjek S1 menyadari bahwa dengan memikirkan untuk merencanakan bangun ruang, ukuran bangun ruang dan pertanyaan pada masalah yang dipikirkan maka ia merasa yakin akan dapat menyelesaikan masalah yang direncanakan dengan mudah. Hal ini sependapat dengan Desoete (2001) bahwa orientasi keterampilan dalam memprediksi dapat membuat pekerjaan seseorang menjadi lebih cepat bila permasalahannya sudah dikenal.

\section{Kesimpulan}

Berdasarkan hasil analisis data diatas, dapat disimpulkan bahwa subjek S1 telah melakukan aktivitas metakognisi dalam merencanakan, memantau dan mengevaluasi proses dan hasil berpikirnya pada setiap tahapan pengajuan masalah sedangkan subjek S2 tidak melakukan aktivitas metakognisi dalam evaluasi dalam menyelesaikan masalah dikarenakan tidak mempunyai cukup pengetahuan dalam menyelesai- 
kan masalah yang dibuat dan subjek S2 juga tidak melakukan aktivitas metakognisi dalam merencanakan dalam memeriksa kembali kesesuaian masalah yang sudah dibuat dengan informasi sebelumnya.

Berdasarkan hasil penelitian tersebut, dapat disarankan bagi guru agar memperhatikan dan mengembangkan kemampuan metakognitif siswa dalam proses pembelajaran, guna meningkatkan kemampuan pengajuan masalah maupun penyelesaian masalah dan bagi yang ingin meneliti lebih lanjut tentang proses metakognitif dalam pengajuan masalah diharapkan lebih spesifik dengan meninjau berdasarkan kemampuan matematika, gender, gaya kognitif maupun yang lain.

\section{Daftar Pustaka}

Abdussakir. (2009). Pembelajaran Matematika dengan Problem Posing. Diakses pada 25 Februari 2016, dari https://abdussakir.wordpress.com/ 2009/02/13/pembelajaranmatematika-dengan-problemposing/

Arends, R. I. (1997). Classroom Instruction and Management. New York: McGraw Hill.

Budiarto, M. T. (2000). Pembelajaran Geometri dan Berpikir Geometri. Prosiding Seminar Nasional Matematika, 2 November 2000. Surabaya: Jurusan Matematika FMIPA ITS Surabaya.
Dawson, T. L. \& Fucher, K. (2008). Metacognition and Learning Adulthood, Contemporary Education Psychology (Vol.11, pp.233-236).

Desoete, A. (2007). Evaluating and Improving the Mathematics TeachingLearning Process Through Metacognition. Electronic Journal of Research in Educational Psychology (Vol. 5, pp. 169-209).

Flavell, J. H. (1979). Metacognitive and cognitive monitoring: A new area of cognitive-developmental inquiry.

American Psychologist, 34, pp. 906911.

Gagne, R.M., Briggs, L.J., \& Wager, W.W. (1992). Principles of Instructional Design. New York: Harcourt Brace Javanovich College Publishers.

Karnain, T. (2014). Exploring the metacognitive skills of secondary school students use during problem posing. Jurnal Teknologi, 67(1), pp. 27-32.

Kuzle, A. (2011). Pattern of metacognitive behaviour during mathematics problem solving in a dynamic geometry environment. Diakses pada 10 Desember 2015, dari www.jwilson.coe.uga.edu

NCREL. (1995). Metacognition in Strategic Teaching and Reading Project Guidebook. Diakses pada 11 Desember 2016. dari http://www.ncrel.org/sdrs/areas/i ssues/students/learning/Ir1metp.ht $\mathrm{m}$.

NCTM. (2007). Principles and Standards for School Mathematics. Reston, VA: National Council of Teachers of Mathematics. 
Resnick, L. B. (1987). Education and learning to think. Washington, D. C: National Academy Press.

Siswono, T. Y. E. (2002). Proses berpikir siswa dalam pengajuan soal. Jurnal nasional matematika, jurnal matematika atau pembelajarannya. pp. 44-50.

Sudia, (2013). Profil Metakognisi Siswa yang Bergaya Kognitif Impulsif-Reflektif dalam Memecahkan Masalah Terbuka Materi Geometri Ditinjau dari Perbedaan Jenis Kelamin. Disertasi UNESA.

Sugiyono. (2011). Metode penelitian kuantitatif kualitatif dan RED. Bandung: Alfabeta

Yeap, B. H. (1997). Mathematical Problem Solving: A focus on metacognition. Unpublished M.Ed. Dissertation. Singapore: Nanyang Technological University. 
